\title{
Coverage of Poland's EU presidency in Romanian printed press and online media - a descriptive analysis
}

\section{Introduction}

\begin{abstract}
ccording to communication theory, news media do not reflect reality, but they filter and shape it (McCombs, Shaw, 1972). The media only cover a select number of topics which often leads audiences to perceive those issues as being the most important (McCombs, Bell, 1996). It is generally accepted now by media researchers that "the press does not tell people what to think, but does tell them what to think about" (McCombs, Shaw, 1977). In contemporary societies, newspapers are a major source of factual information, opinion and analysis. They impart knowledge, influence the understanding of issues by their readers and may also act as advocates for the recipients of news items. Newspapers are less likely to grab attention on low salience stories unless presented in a manner designed to attract attention (Neuman, Rust, Crigler, 1992).

In line with the literature on media representations, the article analyzes the coverage of Poland's EU presidency in the Romanian printed press and online media and tries to offer some answers to the following research questions:

RQ1. How much attention did the Romanian media pay to Poland and Poland's EU presidency?

RQ2. What kind of EU-related topics were covered most frequently by the Romanian media?

RQ3. What were the journalistic framing techniques used to build a positive image of Poland within the Romanian media?
\end{abstract}

\section{Theoretical background}

The agenda setting effect contends that "the news sets the public opinion agenda, bringing some issues to the forefront and minimizing others" (Krippendorff, Bock, 2009, p. 205). In this view, “media content doesn't tell 
so much the audience what to think as it tells the audience what to think about" (Krippendorff, Bock, 2009, p. 205). While the media tell the public what to think about through the process of agenda setting, they tell the public how to think about different issues by emphasizing specific information and downplaying other information (McCombs, Shaw, Weaver, 1997). McCombs and Shaw refer to framing as "second-level agenda-setting" (McCombs, Shaw, Weaver, 1997). The theory of framing was introduced by Gitlin's (1980) study on how a television network trivialized a student movement, which concluded that framing has the ability to do three things: establish the scope of a movement, critique ways of dealing with the issue, and describe the moves made by activists and officials (McCombs, Bell, 1996).

Entman (1993) continued the research into framing and consolidated a definition that is widely used. He described the process as the selection and omission of information in order to produce opinions. Information that is preferred or intended to inform the public will be selected as more salient, while the rest will be unselected in order to hide conflicting information. Entman (1993) explains four aspects of the framing process: define problems, diagnose causes, make moral judgments, and suggest remedies. First, frames can diagnose problems by determining what a causal agent is doing positively or negatively, and is usually judged by the norms of a culture. Second, the frames identify the sources that create an issue by diagnosing causes. Third, the frames can judge whether a causal agent is good or bad by making moral judgments. Fourth, these frames can suggest remedies by offering and justifying solutions for a problem. Entman (1993) clarifies the definitions by saying a frame can perform all, none, or one of these functions in just one sentence. Framing theory is, thus, useful when examining news about the Polish EU presidency because it guides the study on how specific political topics are covered.

\section{Data set and methodology}

On the basis of the 'methods' triangulation' principle, and for reasons of validity, in the quantitative content analysis performed, the current research study employed the theme as the main analysis unit (Holsti, 1969). The Romanian media were selected on the basis of their market quotas in online and offline environments - that is, according to the statistics of the Romanian Bureau for Audience Audit (BRAT) for 2011 and 2012. There were nine Romanian media outlets considered: six newspapers - Adevarul 
(The Truth), Jurnalul National (The National Journal), Romania Libera (The Free Romania), Libertatea (The Freedom), Click; three 'aggregate' sites - Ziare.com, Hotnews and EurActiv; and one magazine - Revista 22 (22 Review). There were six months analyzed in the research period, June 1, 2011 - January 15, 2012. All media stories about Poland were selected and examined. This resulted in a total of 2,715 articles analyzed - 1,668 articles published in newspapers and 1,047 articles in online media. The unit of analysis was the article. In order to test intercoders reliability for the total sample analyzed we choose Cohen's Kappa - $(k)$, which measures the agreement between the evaluations of two raters when both are rating the same object. The $k$ values for the variables from the total newspaper files varied between 0.442 and 0.3117 . The $k$ values for the variables from the online files varied between 0.467 and 0.387 .

\section{Data analysis}

\section{Descriptive statistics}

There was a clear focus on what we can call 'raw information', that is news as a journalistic genre, at the level of the entire sample analyzed.

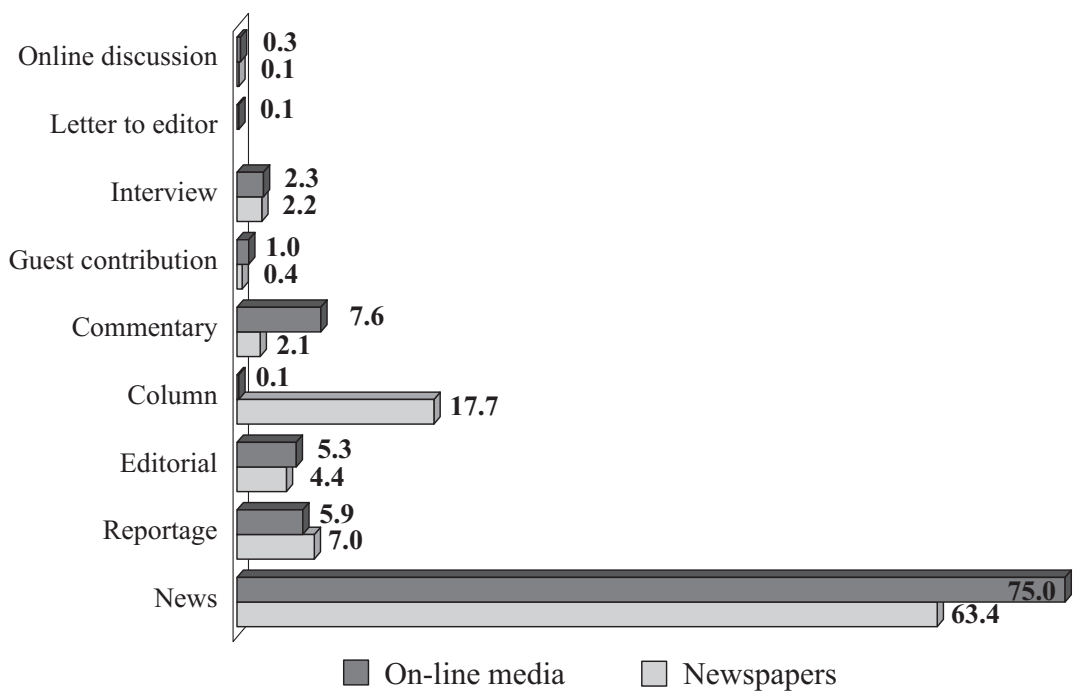

Figure 1. Genres of Romanian articles covering Poland's EU presidency (\%) 
News about Poland and Poland's EU presidency represents 63.4 percent of the total number of articles published in newspapers and 7.9 percent of the total number of articles published online.

At the same time, the opinion-type media materials (commentaries, columns, editorials) were less present in the analyzed sample - for example, columns represented only 17.7 percent of the articles published in newspapers and only 7.6 percent of the total number of articles published online about Poland's EU presidency.

Another aspect of the Romanian media coverage of Poland's EU presidency is its source dichotomy - located both on a national and international scale - as it was presented within the article.

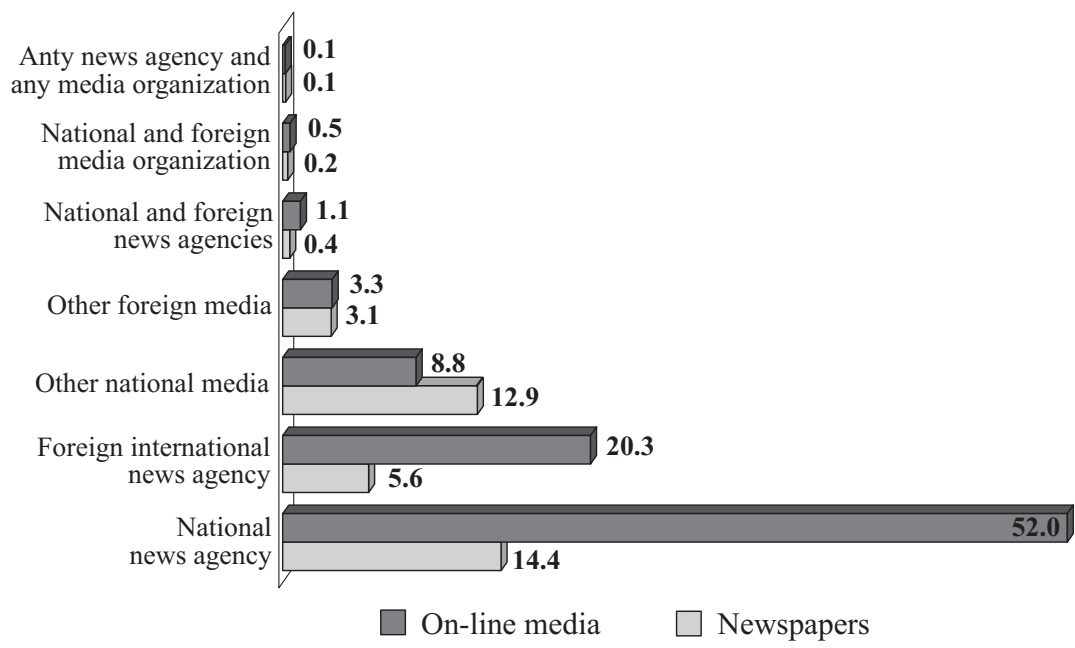

Figure 2. Source of information for the Romanian articles covering Poland's EU presidency $(\%)$

Thus, in the case of newspapers, 14.4 percent of articles invoked information from the national news agency while 5.6 percent of them used international news agencies as the main source of information. For the online articles, there are 52 percent of the articles which used information from the national news agency and 20.3 percent which used international news agencies as a source.

The relevance of Poland's EU presidency as a public topic differs a lot between the two types of media outlets, online media locating articles on it more frequently on the first page of websites, as compared with the news- 
papers. Thus, only 8.6 percent of the articles published in Romanian newspapers are located on the front page, while 44.3 percent of articles from the online media which cover the same subject were located on the top page of the websites. Thus, only 8.6 percent of the articles published within the Romanian newspapers are located on the front page, while 44.3 percent of articles from the online media which cover the same subject were located on the top page of the websites. This difference in location points out the

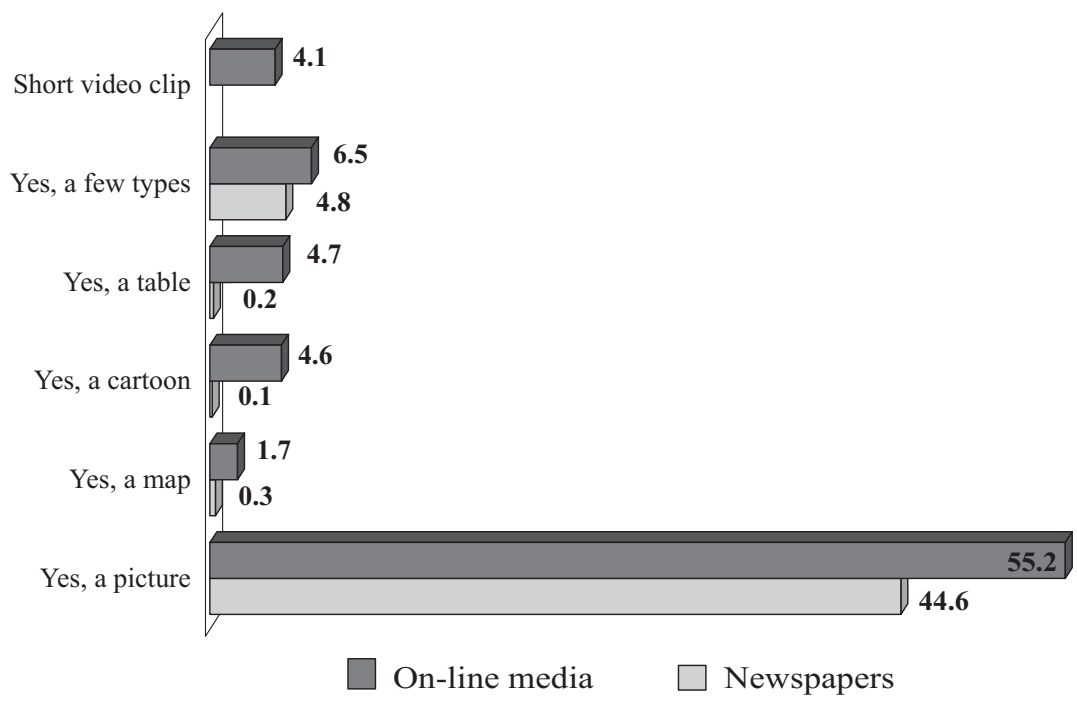

Figure 3. Visual elements published together with the Romanian articles covering the Poland's EU presidency (\%)

preeminence of Poland's EU presidency as a general topic within the general agenda of the Romanian media.

The predominance of visual elements (44.6 percent of the newspapers' articles and 55.2 percent of online articles have a photo or a video published together with them) points out the relevance of informative elements in the general flow of messages delivered related to the issue of Poland's EU presidency. But only 10.8 percent of the visuals published in the Romanian newspapers have relevance to the topic of Poland's EU presidency, as compared with 25.8 percent of those visuals published in the Romanian online media. This obvious dichotomy between printed and online Romania media stressed, again, the preeminence of this topic within the general agenda of the Romanian media. 


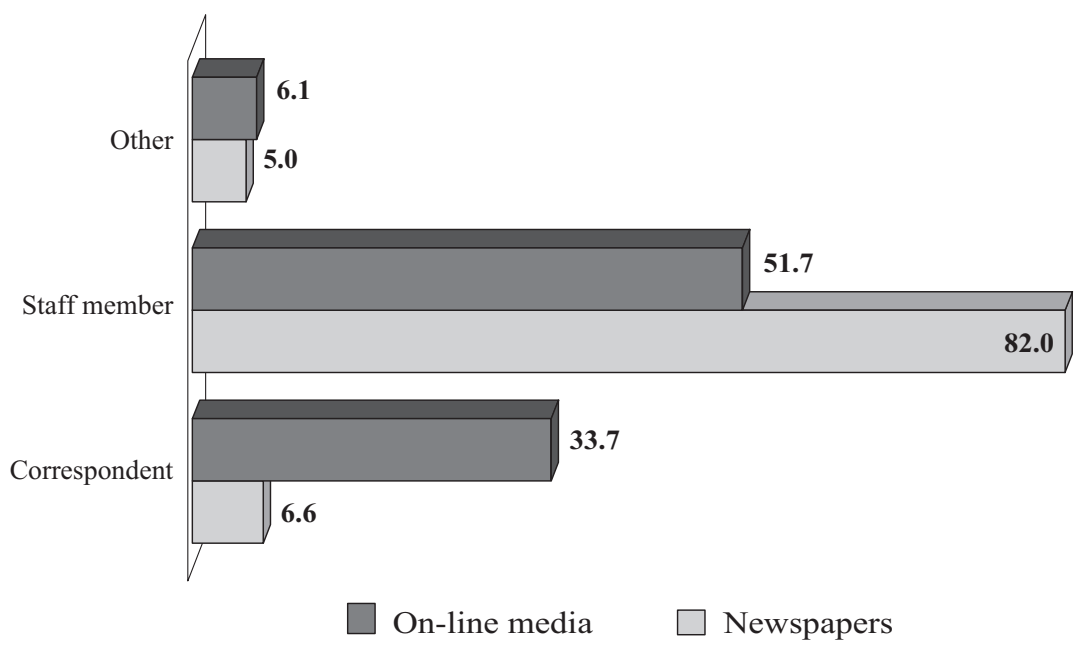

Figure 4. Identity of the author of the Romanian news covering Poland's EU presidency $(\%)$

Staff members are the authors of the news covering Poland's EU presidency in the majority of cases -82 percent for newspaper materials and 51.7 percent in the case of online media.

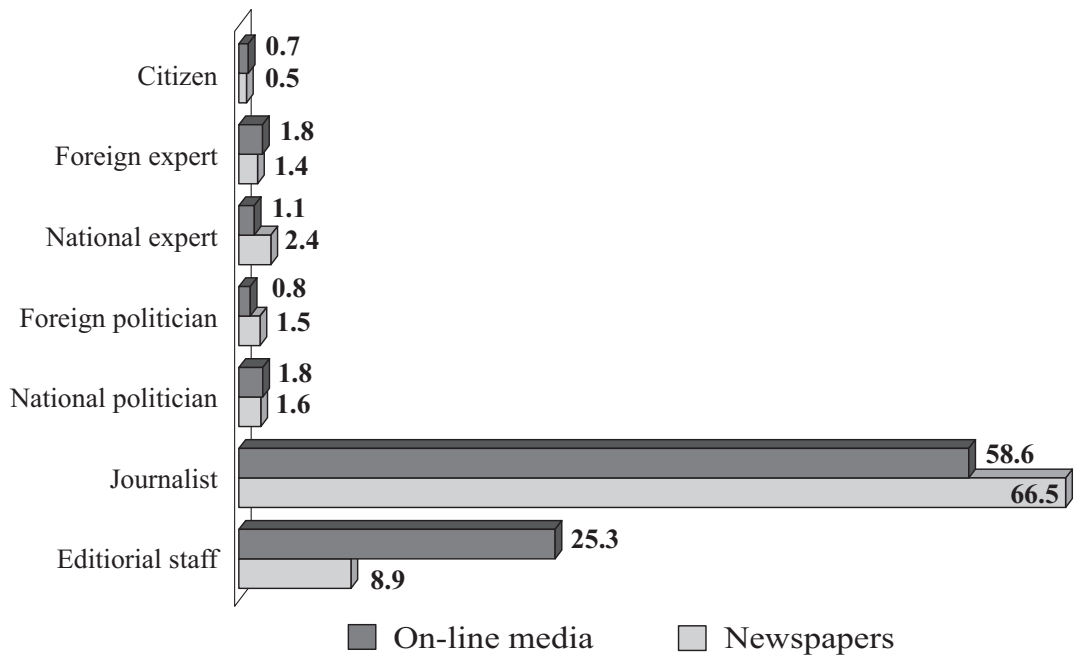

Figure 5. Identity of the author of the Romanian opinion articles covering Poland's EU presidency (\%) 
This focus on organizational resources (e.g. the use of media outlet's employees in producing the news and opinion articles) could also be noticed in the case of opinion articles about Poland's EU presidency: 66.5 percent of opinion articles published in newspapers and 58.6 percent of those published in online media have journalists as authors.

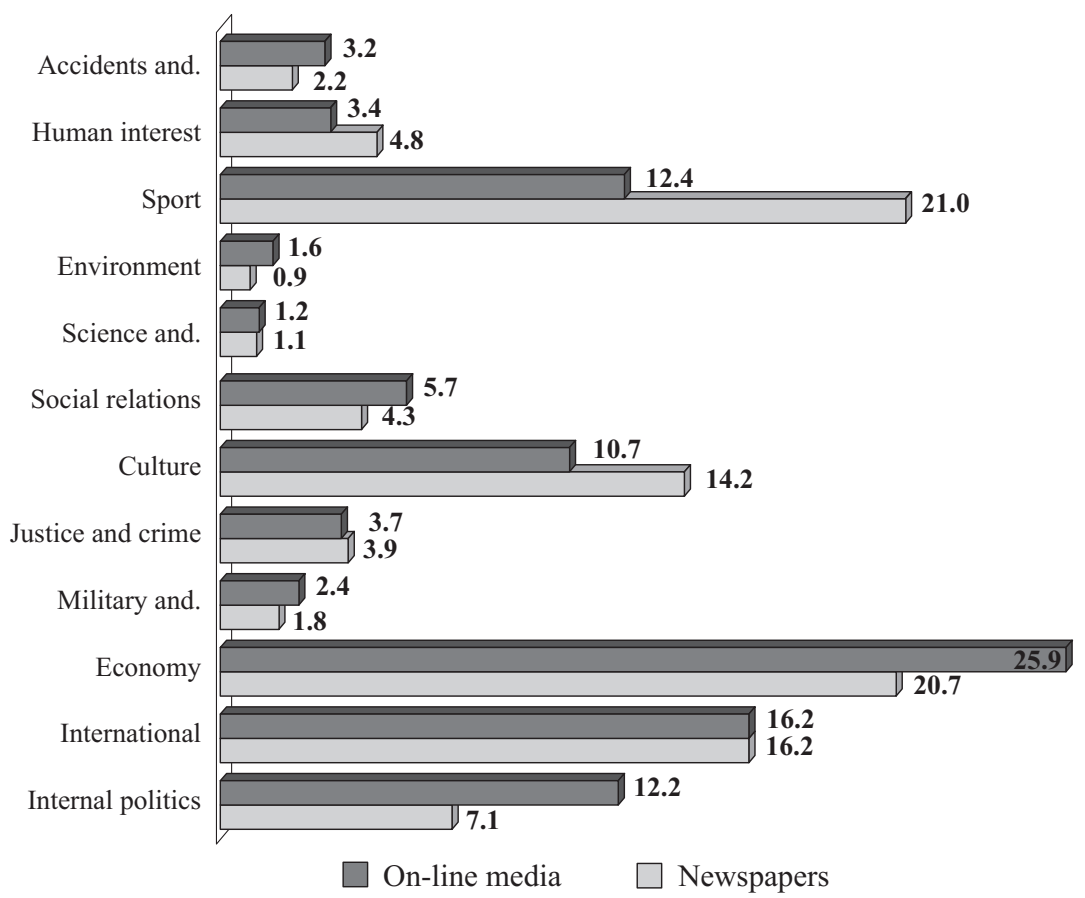

Figure 6. The dominant topics of the Romanian articles covering Poland's EU presidency (\%)

Economy is the most important, dominant topic in the articles analyzed, 20.7 percent of the newspapers' articles and 25.9 percent of the online materials covering it. International politics comes second - 16.2 percent of materials published in both type of media (newspapers and online media) covering it, while sport comes in the third place as a dominant topic -21 percent of the newspapers' articles and 12.4 of Romanian online materials covering issues related to it. The hierarchy of the main topics of the Romanian newspapers' articles covering Poland's EU presidency showed that the issue of arts ( 7.4 percent) was placed in first place, 
followed by EU relations (6.6 percent) and festivals and competitions (5.5 percent).

At the same time, in the case of online media, the hierarchy of main topics of the Romanian articles covering Poland's EU presidency showed that the issue of the state of economy (5.3 percent) is in first place, followed by EU relations ( 4.5 percent) and by arts ( 4.1 percent). As such, one can notice clear differences between the newspapers' hierarchy of main topics related to Poland's EU presidency and that of the online media (see Figure 8). Although both types of media cover seven common topics, only in the case of investments and business and commerce there is the difference in coverage between the newspapers and online media of less than one percent. The greatest differences in coverage of a common topic are recorded in the case of arts (7.4 percent of articles published in newspapers vs. 4.1 percent of articles published in the online media) and economic crisis ( 5 percent of articles published in the newspapers vs. 2.2 percent of the articles published in the online media).

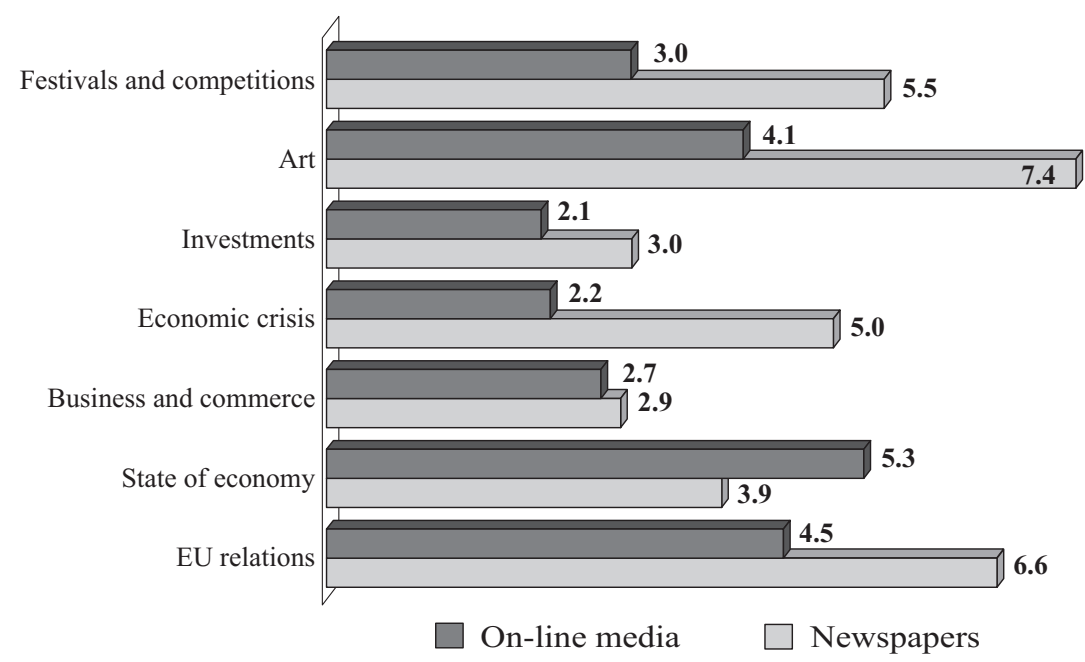

Figure 7. Common main topics of the Romanian articles covering Poland's EU presidency $(\%)$

The analysis of the 'domestication' item (that is, explicit reference to Romanian nationals and/or to the impact on Romania used in the article) shows both similarities and differences between Romanian newspapers and online media in covering the issue of Poland's EU presidency. 


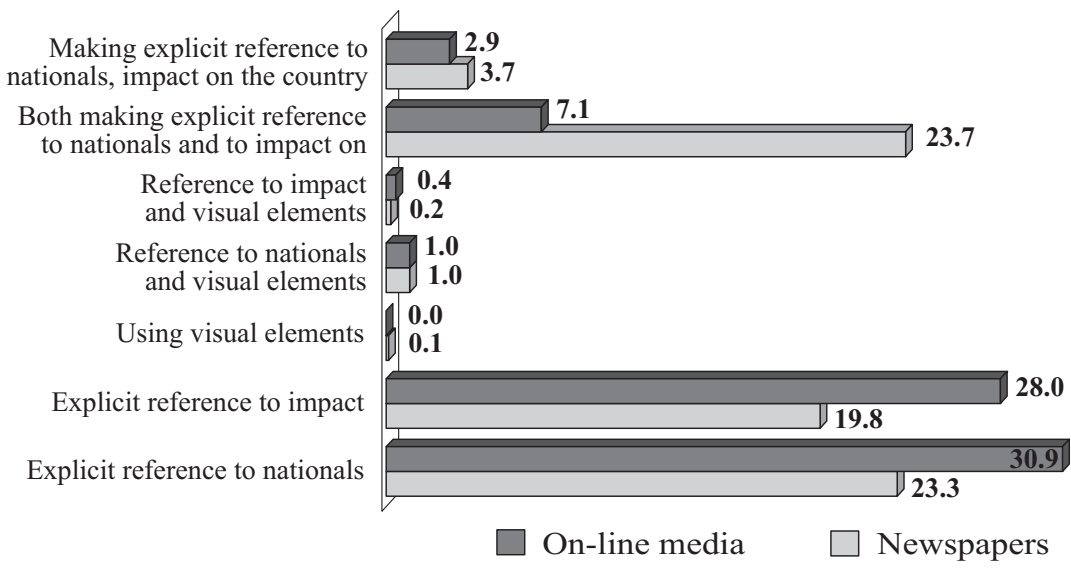

Figure 8. Explicit reference to Romanian nationals and/or the impact on Romania in articles covering Poland's EU presidency (\%)

Thus, both types of media put a greater stress on explicit references to Romanian nationals than on the impact on the country. In the newspapers' case, 23.3 percent of the articles made reference to Romanians as compared with 19.8 percent that made reference to the impact on Romania while the data for the online media are 30.9 percent of articles which made reference to Romanians vs. 28 percent of them which made reference to the impact on Romania. At the same time, one can notice clear evidence that the mix of references to Romanians with reference to the impact on Romania is more frequently used in Romanian newspapers than in online media -23.7 percent of the newspapers' articles used it in comparison to only 7.1 percent of articles from the online media. Only 15.7 percent of the articles covering issues related to Poland also explicitly mentioned the topic of Poland's EU presidency, while this percentage is doubled in the case of materials on the same topic published in Romanian online media -36.2 percent.

Taking into account the above-mentioned results, it is not surprising that the most frequently used frame related to Poland in Romanian articles covering Poland was 'member of the EU' - 35.7 percent in the case of newspapers and 61 percent in the case of online media. Only 3 percent of newspaper articles and 6.3 of those published in the online media framed Poland as a 'new EU member' while the frame 'post-communist country' is used in few cases -1.1 percent of the articles published in the online media and 2.4 percent of those published in Romanian newspapers. 


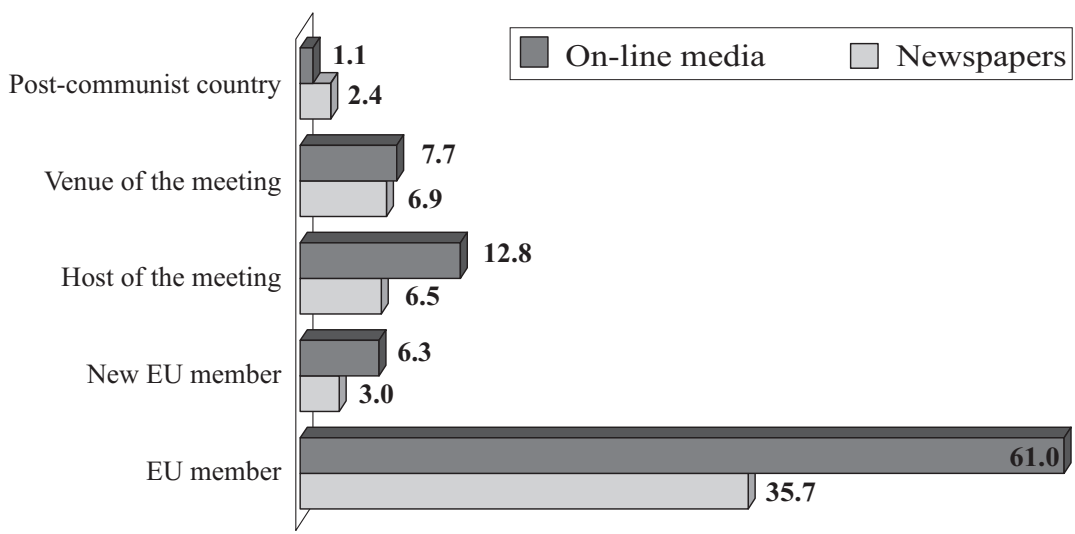

Figure 9. The most frequently used frames related to Poland in Romanian articles covering Poland's EU presidency (\%)

The majority of articles published both in newspapers and in online media used a neutral attitude towards Poland -61.8 percent of the articles published in online media and 75.4 percent of those published in newspapers.

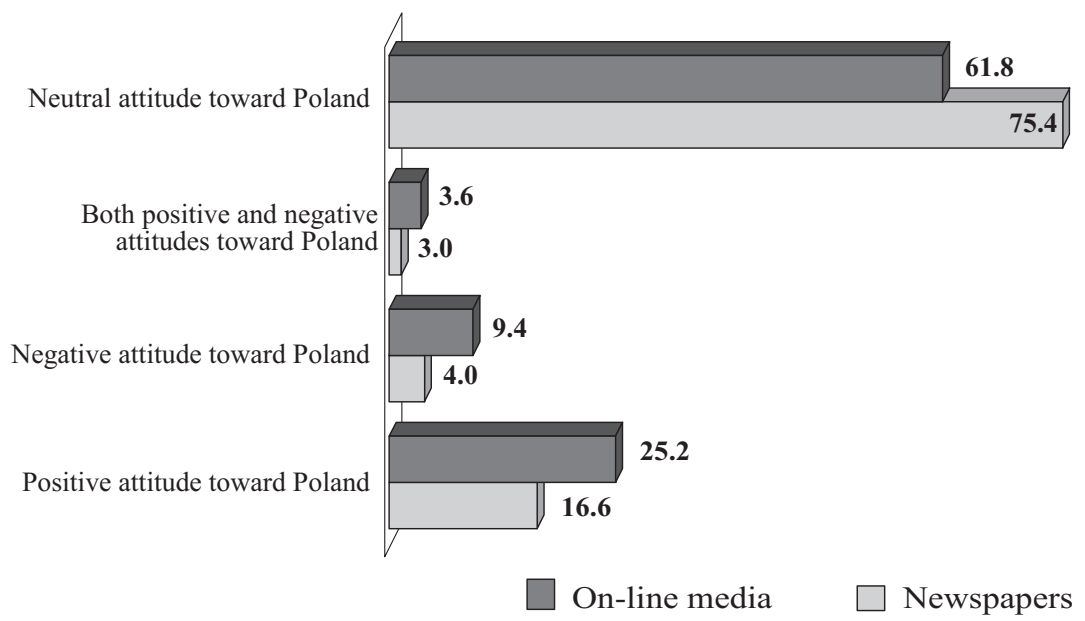

Figure 10. Attitude towards Poland in the Romanian articles covering Poland's EU presidency (\%)

At the same time, a positive attitude in covering Poland's EU presidency was recorded in 25.2 percent of the online materials and in 16.6 percent of the newspapers' articles. 
Some elements of the inferential statistics

If we consider the three dominant genres of Romanian (newspapers and online) articles (news, reports and editorial) we could notice that in the case of Romanian media, as a journalistic genre, news (both in newspapers and in online media) has the greater importance for explaining the relevance of the topic of Poland's EU presidency within the period of time considered.

Table 1

Correlation between the genre of media material (news, editorial, report) and relevance of the topic of Poland's EU presidency for the article

\begin{tabular}{||l|l|c|c|c||}
\hline \hline & & News & Report & Editorial \\
\hline \multirow{2}{*}{$\begin{array}{l}\text { Topic ‘The EU presidency' is re- } \\
\text { levant to the article - newspapers }\end{array}$} & Pearson Correlation & $\mathbf{0 . 1 1 3} * *$ & -0.031 & 0.040 \\
\cline { 2 - 5 } & Sig. (2-tailed) & 0.000 & 0.205 & 0.100 \\
\hline \multirow{2}{*}{$\begin{array}{l}\text { Topic 'The EU presidency' is re- } \\
\text { levant to the article - online media }\end{array}$} & Pearson Correlation & $\mathbf{0 . 1 3 3} * *$ & -0.014 & -0.021 \\
\cline { 2 - 5 } & Sig. (2-tailed) & 0.000 & 0.644 & 0.493 \\
\hline
\end{tabular}

* Correlation is significant at the 0.05 level (2-tailed)

** Correlation is significant at the 0.01 level (2-tailed).

If, in the case of newspapers, economy and sport as dominant topics, and the relevance of the topic of Poland's EU presidency have explanatory powers related to the articles' positive attitudes towards Poland, the same set of factors do not show any significant explanatory powers in the case of online media.

Table 2

Correlation among the positive attitude towards Poland in articles, dominant topics (economy and sport) and relevance of the topic of Poland's EU presidency for the article

\begin{tabular}{||l|l|c|c|c||}
\hline \hline & $\begin{array}{c}\text { Economy } \\
\text { as dominant } \\
\text { topic }\end{array}$ & $\begin{array}{c}\text { Sport as } \\
\text { dominant } \\
\text { topic }\end{array}$ & $\begin{array}{c}\text { Topic 'The EU } \\
\text { presidency' is rele- } \\
\text { vant to the article }\end{array}$ \\
\hline $\begin{array}{l}\text { Positive attitude towards } \\
\text { Poland in newspapers }\end{array}$ & Pearson Correlation & $\mathbf{0 . 1 4 2 * *}$ & $\mathbf{- 0 . 1 6 3 * *}$ & $\mathbf{0 . 1 1 2 ( * * )}$ \\
\cline { 2 - 6 } & Sig. (2-tailed) & 0.000 & 0.000 & 0.000 \\
\hline $\begin{array}{l}\text { Positive attitude towards } \\
\text { Poland in online media }\end{array}$ & Pearson Correlation & -0.033 & -0.004 & 0.048 \\
\cline { 2 - 5 } & Sig. (2-tailed) & 0.282 & 0.907 & 0.121 \\
\hline
\end{tabular}

* Correlation is significant at the 0.05 level (2-tailed)

** Correlation is significant at the 0.01 level (2-tailed). 
As a journalistic genre, news has greater importance for explaining the relevance of economy and sport as dominant topics, both in the case of Romanian newspapers and online media.

Table 3

Correlation among dominant topics (economy and sport) and genre of media material (news, editorial, reports)

\begin{tabular}{|c|c|c|c|c|}
\hline & & News & Report & Editorial \\
\hline \multirow{2}{*}{$\begin{array}{l}\text { Economy as dominant } \\
\text { topic-newspapers }\end{array}$} & Pearson Correlation & -0.006 & 0.007 & 0.016 \\
\hline & Sig. (2-tailed) & 0.798 & 0.771 & 0.520 \\
\hline \multirow{2}{*}{$\begin{array}{l}\text { Economy as dominant } \\
\text { topic-online media }\end{array}$} & Pearson Correlation & $-0.106 * *$ & 0.143 ** & -0.009 \\
\hline & Sig. (2-tailed) & 0.001 & 0.000 & 0.782 \\
\hline \multirow{2}{*}{$\begin{array}{l}\text { Sport as dominant topic } \\
\text { - newspapers }\end{array}$} & Pearson Correlation & 0.141 ** & -0.049 & $-0.121 * *$ \\
\hline & Sig. (2-tailed) & 0.000 & 0.056 & 0.000 \\
\hline \multirow{2}{*}{$\begin{array}{l}\text { Sport as dominant topic } \\
\text { - online media }\end{array}$} & Pearson Correlation & 0.140 ** & -0.044 & $-0.087 * *$ \\
\hline & Sig. (2-tailed) & 0.000 & 0.158 & 0.005 \\
\hline
\end{tabular}

* Correlation is significant at the 0.05 level (2-tailed)

** Correlation is significant at the 0.01 level (2-tailed).

We can, as such, propose a possible model of the relations between explanatory factors of the positive coverage of Poland's EU presidency in Romanian newspapers and online media.

On-line media

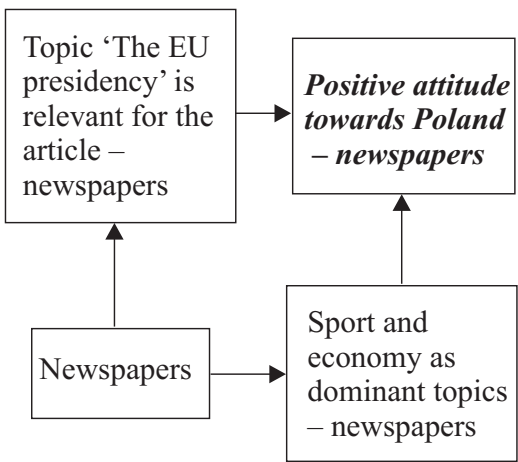

Newspapers

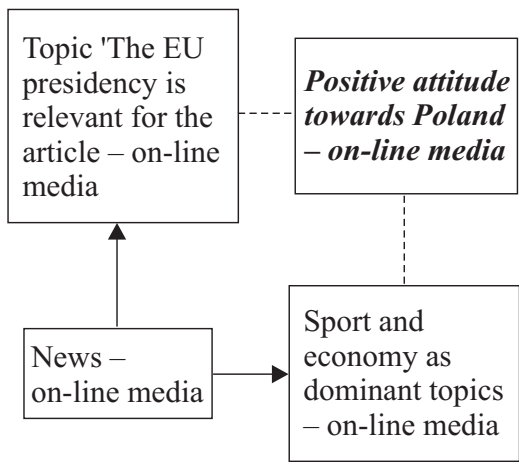

Figure 11. Possible model of the relations between explanatory factors for the positive coverage of Poland's EU presidency in Romanian media - newspapers vs. online media 
We noticed that the positive attitude towards Poland cannot be explained by the same set of factors in the case of Romanian newspapers and online media. In the case of Romanian newspapers there are clear relations between news (as a journalistic genre), the dominant topics (sport and economy), the relevance of the topic of the EU presidency for the articles and the positive attitude of the article towards Poland. For the Romanian online media the set of causal links among various factors enclosed in the analysis is broken. There are clear causal relations among journalistic genre (news), dominant topics (sport and economy) and the relevance of the topic of the EU presidency, but none of those factors can explain the articles' positive attitude towards Poland (see Figure 11).

\section{Conclusions}

The media have a crucial role in communicating and informing public opinion, and beyond this, have multiple complex effects on society. The media provide information, frame policy issues, persuade readers and can influence the policy agenda (Iyengar, 1997). Orientation of newspaper coverage - negative or positive, attraction or aversion, favorable or unfavorable orientation - implicit in news coverage, has been an important feature of commentary in the performance of the press in open societies (Gunther, 1998). Journalists can influence the orientation of coverage by their choice of terminology, the tag lines with which they lead, the tone they use, and the experts they choose to interview and quote (Christen et al., 2002). Intentionally or not, this orientation structures how most readers interpret news events (Price et al., 1997) and can help to frame public opinion (Jeon, Haider-Markel, 2001). Accordingly, we expect coverage of the Polish EU presidency system and its reform to reflect certain orientations and framing devices, as is true of other public policy issues.

Our analysis shows that the coverage of Polish EU presidency is similar in Romanian newspapers and online media. One can notice that Poland's EU presidency was presented mainly in news, both in Romanian newspapers and Romanian online media. Sport, economy and international politics were the main topics covered by the Romanian newspapers and online media in relation to Poland's EU presidency. At the same time, the general topic of Poland's EU presidency was not covered in a similar manner by Romanian newspapers and online media. If in the case of Romanian newspapers there are clear relations between the journalistic genre 
and the dominant topics, the relevance of the topic of the EU presidency and the positive attitude of the article towards Poland, those relations are broken in the case of Romanian online media.

\section{References}

Christen C. T., Kannaovakun P., Gunther A. C. (2002), Hostile Media Perceptions: Partisan Assessments of Press and Public during the 1997 United Parcel Service Strike, "Political Communication", no. 19(4), pp. 23-36.

Entman R. M. (1993), Framing: Toward clarification of a fractured paradigm, "Journal of Communication", no. 43(4), pp. 51-58.

Gitlin T. (1980), The world is watching: Mass media in the making \& unmaking of the new left, University of California Press, Los Angeles, CA.

Gunther A. C. (1998), The Persuasive Press Inference: Effects of Mass Media on Perceived Public Opinion, "Communication Research", no. 25 (5), pp. 486-504.

Holsti O. (1969), Content analysis for the social sciences and humanities, Addison-Wesley, Reading MA.

Iyengar S. (1997), Overview, in: Do the Media Govern? Politicians, Voters and Reporters in America, eds. S. Iyengar, R. Reeves, Sage Publications, Thousand Oaks, CA, pp. 211-216.

Jeon Y., Haider-Markel D. P. (2001), Tracing Issue Definition and Policy Change: An Analysis of Disability Issue Images and Policy, "Policy Studies Journal", no. 29(2), pp. 215-37.

Krippendorff K., Bock M. A. (2009), The Content Analysis Reader, Sage Publications, Los Angeles, California.

McCombs M., Bell T. (1996), The agenda-setting role of mass communication, in: An integrated approach to communication theory and research, eds. M. B. Salwen, D. W. Stacks, Lawrence Erlbaum Associates, Mahwah, NJ, pp. 93-110.

McCombs M., Shaw D. (1972), The agenda-setting function of mass media, "Public Opinion Quarterly", no. 36(2), pp. 176-187.

McCombs M. E., Shaw D. L. (1977), The agenda-setting function of the press, in: The Emergence of American Political Issues: The Agenda-Setting Function of the Press, eds. D. L. Shaw, M. E. McCombs, West Publishing Co., Saint Paul, Minnesota, pp. 1-18.

McCombs M. E., Shaw D. L., Weaver D. H. (1997), Communication and democracy: Exploring the intellectual frontiers of agenda-setting theory, Erlbaum, Mahwah, NJ.

Neuman W. R., Just M. R., Crigler A. N. (1992), Common Knowledge-News and the Construction of Political Meaning, The University of Chicago Press. 
Price V., Tewksbury D., Powers E. (1997), Switching Trains of Thought: The Impact of News Frames on Readers' Cognitive Responses, "Communication Research", no. 24(5), pp. 481-507.

\begin{abstract}
Journalists make use of the main 'frameworks' of interpretation of the world and of the events which they present in news items and other media products. Professional routines lead journalists to search for information first in sources which have, in their opinion, the power to 'define' the situation and to 'frame' it. The article analyzes the coverage of Poland's EU presidency in the Romanian printed press and online media. The analysis was made on a sample of data composed of Romanian articles devoted to Poland's EU presidency in July 2011-January 2012. The study highlights the similarities in covering Polish presidency of the EU between the Romanian newspapers and online media. At the same time, the results showed that the attention paid by the Romanian mass media to Poland's EU presidency varied according to the type of media where the article was published: newspapers vs. online media.
\end{abstract}

